\title{
Surgical treatment of type I Chiari malformation: the role of Magendie's foramen opening e tonsils manipulation
}

Tratamento cirúrgico da malformação de Chiari do tipo I: importância da abertura do forame de Magendie e manipulação das tonsilas

Claudio Henrique Fernandes Vidal

Resumo da Tese de Doutorado apresentada ao programa de Pós-Graduação em Neuropsiquiatria e Ciência do Comportamento da Universidade Federal de Pernambuco, Centro de Ciências da Saúde. Área de Neurocirurgia. 2014. Recife PE, Brasil.

Correspondence: Claudio Henrique Fernandes Vidal; Rua Francisco da Cunha, 206; 51020-041 Recife PE, Brasil; E-mail: vidal-claudio@ig.com.br

Orientador: Marcelo Moraes Valença.

Received 29 September 2014; Received in final form 10 October 2014; Accepted 30 October 2014.

\begin{abstract}
The treatment for type 1 Chiari malformation (CM 1) is one of the most controversial topics in the neurosurgical field. The present study evaluated two of the most applied surgical techniques to treat CM 1. Method: 32 patients were evaluated and divided in two groups: group 1 had 16 patients that were submitted to decompression of occipital bone and dura mater of the craniovertebral junction (CVJ); group 2 also had 16 patients and in addition to the previous procedure, they were submitted to Magendie's foramen opening e tonsils manipulation. The comparison between the groups included neurological exam and cerebrospinal fluid flow imaging during pre and postoperative periods. Results: Both techniques were equivalents in terms of neurological improvement of the patients ( $p>0.05)$, but the group 2 had more surgical complications, with relative risk of $2.45(\mathrm{Cl} 1.55-3.86)$ for adverse events. Whatever the cerebrospinal fluid flow at CVJ, the patients of the group 1 achieved greater amount of flow than the group 2 ( $p<0.05$ ) during the postoperative period. Conclusion: The cranial and dural decompression of the CVJ without arachnoidal violation was the best surgical intervention for treatment of CM 1 , between these two compared techniques.
\end{abstract}

Keywords: Arnold-Chiari malformation, syringomyelia, cranial fossa, posterior. 